\title{
IMPLEMENTATION OF INTEGRATED SCIENCE INSTRUCTION ASSESSMENT AS AN ALTERNATIVE TO MEASURE SCIENCE PROCESS SKILLS AND SOCIAL ATTITUDES
}

\author{
${ }^{1}$ Sukardiyono, ${ }^{2}$ Dadan Rosana \\ ${ }^{1}$ Physics Education Study Program, Faculty of Mathematics and Science \\ Yogyakarta State University, email: sukarfis@uny.ac.id \\ ${ }^{2}$ Science Education Study Program, Faculty of Mathematics and Science \\ Yogyakarta State University, email: danrosana@uny.ac.id
}

\begin{abstract}
Curriculum 2013 requires a paradigm shift in the teachers manage learning, including assessment. Research on the implementation of integrated science instruction assessmentis an attempt to overcome the problems in science learning assessment in Junior High School. Rate the former tend to simply measure cognitive ability, so that teachers rarely pay attention to ratings on science process skills of students and social attitudes. This research aims to; (1) produce integrated science assessment practical instruction through the feasibility test in science learning class (2) to get the measure of science process skills and social attitudes of learners using instruments developed. This research is a development that adapt the model Borg and Gall (1983). Aiken's Formula V is used to analyze the instrument by the validator. This research resulted in: (1) integrated science instruction assessment practical through feasibility testing in the classroom science lessons with the following characteristics: (a) the observation sheet form checklist used by teachers to observe the science process skills of learners is only at the stage of observing, measuring, inferring, classifying, predicting, communicating as well as observing the social attitude on stage mental and neural state, of readiness to respond, organized, through experience, and exerting a directive (b) science process skills is not observed from the behavior of learners assessed by working the worksheet (c) the self-assessment of social attitudes among learners friends used only at the stage of evaluate; (2) the instrument has been developed fit for use because it meets the content validity by experts and reliability was good value. (3) Results of measurement using observation sheet science process skills get a very good category and the results of measuring social attitude of learners using observation sheets, self-assessment and peer assessment obtained either category on aspects of mental and neural state, of readiness to respond, organized, through experience, and exerting a directive .
\end{abstract}

Keywords: integrated science instruction assessment, science process skills, social attitude

\section{Introduction}

Assessment instrument is one important part of learning in schools. According Arikunto (2011: 26), the assessment tool is one part of the evaluation instrument. Evaluation instrument is one of the measuring instruments used in conducting the evaluation of 
educators learning process and the learning outcomes of students (Arikunto, 2011: 26). According Kuswanto (2008), basically the purpose of science is to master the knowledge of science, understand and apply scientific concepts, apply the process skills, and develop attitudes.

Based on preliminary study of science learning in secondary schools in Yogyakarta, shows that learning science is not yet fully implemented in an integrated manner. It also shows that not many science teachers who develop an integrated assessment and can measure science process skills in students. From the results of the questionnaire also indicated that in schools is necessary to form a science assessment instrument that can measure the scientific attitude and science process skills in students. This can be realized by developing a form of scientific assessment instrument called integrated science instruction assessment.

This research seeks to contribute in education, especially in science learning evaluation process as an alternative form of assessment that can measure science process skills of students by developing integrated science assessment instruction in secondary schools. For the settlement of the issues presented in the learning of science, have tended to be oriented towards academic issues that are covered, often associated with the context. Likewise in learning activities designed teachers, yet emphasizing on skills students use reasoning to argue that students have not been able to express his ideas, either orally or in writing. With untrained students to express ideas and ideas, resulting in a lack of a notion of the students. This will certainly adversely affects the ability of science and science process skills of the students. Assessment attitude that teachers do today, limited to the assessment of social attitudes of a general nature, not intended specifically to assess the attitudes according to the characteristics of materials science subjects presented. Skills assessment has been carried out is also more general, not specific to the particular skills that correspond to the characteristics of materials science.

Learning what happened today just transferring knowledge to students, and still centered on the teacher. This leads to not getting the experience to understand the concept in full by the student. As a result of doing accommodations with concepts that are concrete, the students have not been able to formulate. Among the contributing factor is the model used by teachers less varied, less students are actively involved in the learning of science and the nature of learning are less supportive of science process skills of students.

\section{Research Methods}

This study uses a model of research and development or Research and Development ( $R$ $\&$ D) is a process to develop a new product or improve existing products and can be justified (Sukmadinata, 2013: 164). Stages on research and development shows a cycle which begins with a problem or a need that needs solving problems with a particular product. The products are to be developed in this study of integrated science instruction assessment. Product development in this study adapt the model development by Borg \& Gall. This model was chosen because of its working procedures that detail.

According to Borg \& Gall (1983: 775) there are ten steps in development research include: 1. preliminary research and gathering information, 2. Planning, 3. early product development, limited trial 4., 5. The revision of the main product (revision phase I), 6. field test, 7. the revision of the operational product (revised phase II), 8. operational field trials, 9. 
revision of the final product (revision phase III) and 10. the dissemination and implementation of the product. In this study conducted by the development model adaptation Borg and Gall (1983: 775) so it only made two test which limited testing and field testing operations with equipment through three stages of revision and only perform a limited dissemination without implementation.

Procedure development of integrated science instrument instruction assessment in this study are summarized in the chart in Figure 1.

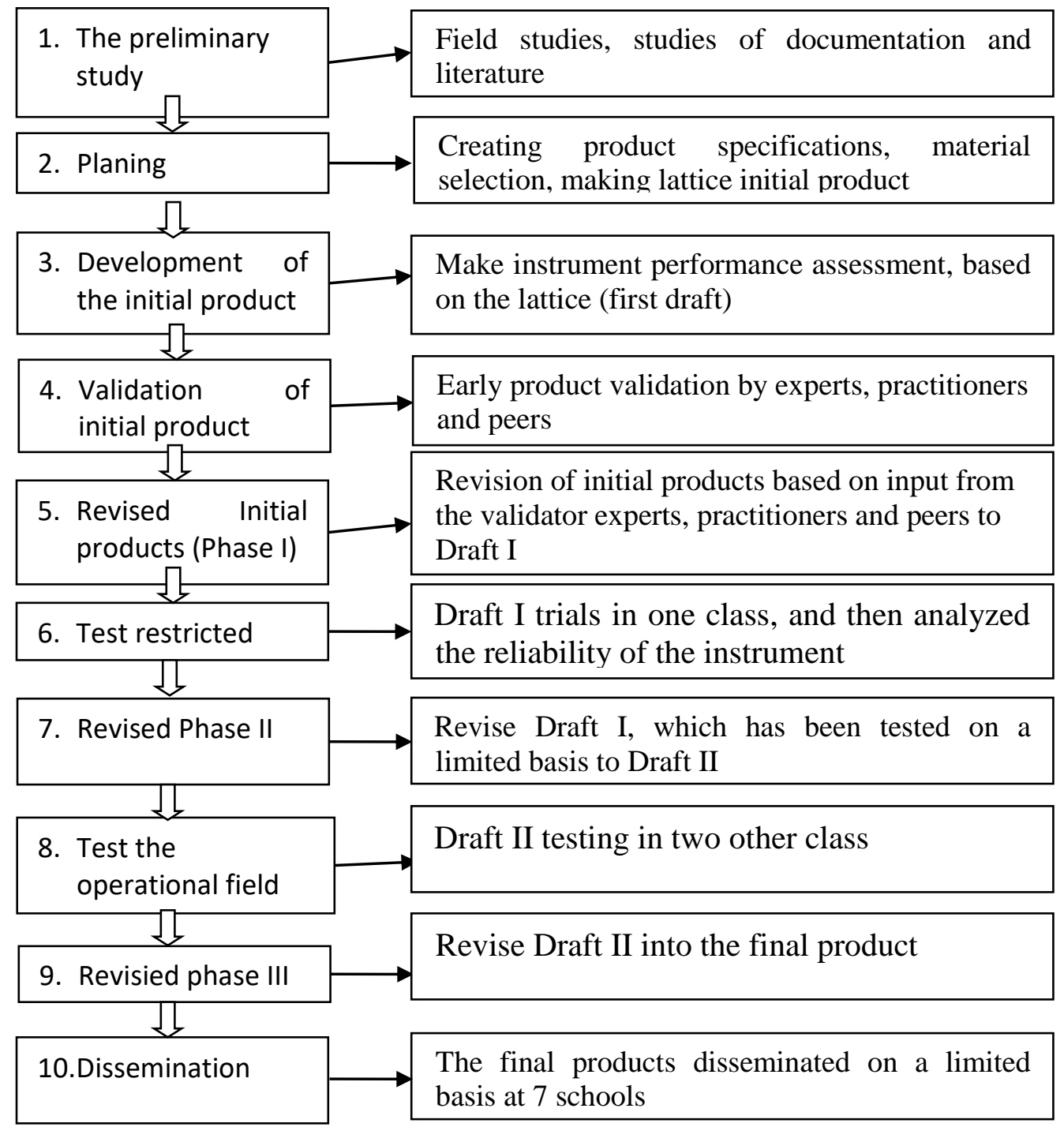

Figure 1. Schematic Instrument Procedure Development of integrated science instruction assessment

Data collection instruments used in this study to validate the theoretical (expert judgment) and reliability testing empirically as summarized in Table 1.

Table 1. Data Collection Instrument 


\begin{tabular}{|c|l|l|l|l|}
\hline No & Validity & \multicolumn{1}{|c|}{ Tecnique } & \multicolumn{1}{|c|}{ Instrument } & Type of data \\
\hline 1 & Theoritical & Questioner & $\begin{array}{l}\text { Sheets validation of products for } \\
\text { evaluation experts, subject matter } \\
\text { experts, practitioners and peers }\end{array}$ & $\begin{array}{l}\text { Quantitative } \\
\text { and Qualitative }\end{array}$ \\
\hline 2 & Empiric & a. Observation & $\begin{array}{l}\text { 1) Observation sheet science } \\
\text { process skills skills } \\
\text { 2) Observation sheet scientific } \\
\text { attitude } \\
\text { 3) Observation sheet } \\
\text { implementation of learning }\end{array}$ & Quantitative \\
& & $\begin{array}{l}\text { Science process skills assessment } \\
\text { based worksheet }\end{array}$ & Quantitative \\
\cline { 3 - 5 } & $\begin{array}{l}\text { b. Rate answer } \\
\text { learners }\end{array}$ & $\begin{array}{l}\text { Rate yourself scientific attitude } \\
\text { assessment }\end{array}$ & Quantitative \\
\cline { 3 - 6 } & $\begin{array}{l}\text { d. Rate Between } \\
\text { Friends }\end{array}$ & $\begin{array}{l}\text { Rate scientific attitude among } \\
\text { friends }\end{array}$ & Quantitative \\
\hline
\end{tabular}

\section{Results and Discussion}

Based on the multiple linear regression analysis to experimental class, that the implementation of integrated science instruction assessment can enhance science process skills of students in learning science. Tersbut relationship is also seen in multiple correlation analysis that for class experiments with $\mathrm{R}$ at 0.699 then there is a strong relationship between the implementation of integrated science instruction assessment to increase students' science process skills by $\mathrm{R}$ of 0.890 . Based on the experimental class determination analysis shows that the contribution of science instruction effect of the application of integrated assessment of student science process skills at $79.2 \%$. To determine the effect of the application of the assessment conducted regression coefficient test (Test F), and it appears that the experimental class no significant effect between the application of science instruction integrated assessment of science process skills based on testing MANOVA there are differences in science process skills between the experimental class and control class. On the measurement of scientific attitude, aspect that is measured through observation sheets, self-assessment and peer assessment the same which includes the curious aspects, objective, critical and open-minded.

Measurement data of scientific attitude of learners through observation, including a recap of the average measurement results at the third meeting of the scientific attitude. Based on these recaps can be found $3.70 \%$ of learners achieving excellent category, $68.52 \%$ good category, and $27.78 \%$ category enough, so in general there are still some students who have not mastered the scientific attitude. 
Analysis of the results of each aspect of the scientific attitude of learners through observation sheet can be seen in Table 2. Scores on each aspect of scientific attitude with a maximum score of 1 is averaged for each meeting.

Table 2. Analysis of Results of Scientific Attitude Measurement Through Observation Sheet

\begin{tabular}{|c|l|c|c|c|c|c|c|}
\hline \multirow{2}{*}{ No } & \multirow{2}{*}{$\begin{array}{c}\text { Aspects of } \\
\text { Scientific } \\
\text { Attitude }\end{array}$} & \multicolumn{2}{|c|}{$\begin{array}{c}\text { Average score } \\
\text { Meeting }\end{array}$} & $\mathbf{1}$ & Average & Avarage & Category \\
\cline { 3 - 6 } & & $\mathbf{1}$ & $\mathbf{3}$ & & Scale 4 & \\
\hline 1 & Curiosity & 0,66 & 0,64 & 0,65 & 0,65 & 2,60 & B \\
\hline 2 & Objective & 0,63 & 0,72 & 0,69 & 0,68 & 2,73 & B \\
\hline 3 & Critical & 0,44 & 0,46 & 0,50 & 0,47 & 1,87 & C \\
\hline 4 & Open minds & 0,63 & 0,65 & 0,72 & 0,67 & 2,67 & B \\
\hline
\end{tabular}

The average yield for each aspect have different score ranges with scientific attitude assessed using the self-assessment and peer assessment, so as to menyetarakannya conversion done using a scale of 4 in accordance with the classification results of the assessment by Widoyoko (2014: 144).

Based on the analysis showed the curious aspects, objective and open-minded've been in both categories, while still lower that the critical aspects in the category enough. Learners are still rare dubious findings of friends and just follow the findings of a friend without rechecking. Not many students are sensitive to the changes that occur during the trial and then ask their friends or teachers. Not all students want to repeat the experiment back to repair the data, this is because the time allowed for a limited trial. Teachers have set the time trial so as not to be protracted in a long time so that all stages of the learning cycle can be implemented. 


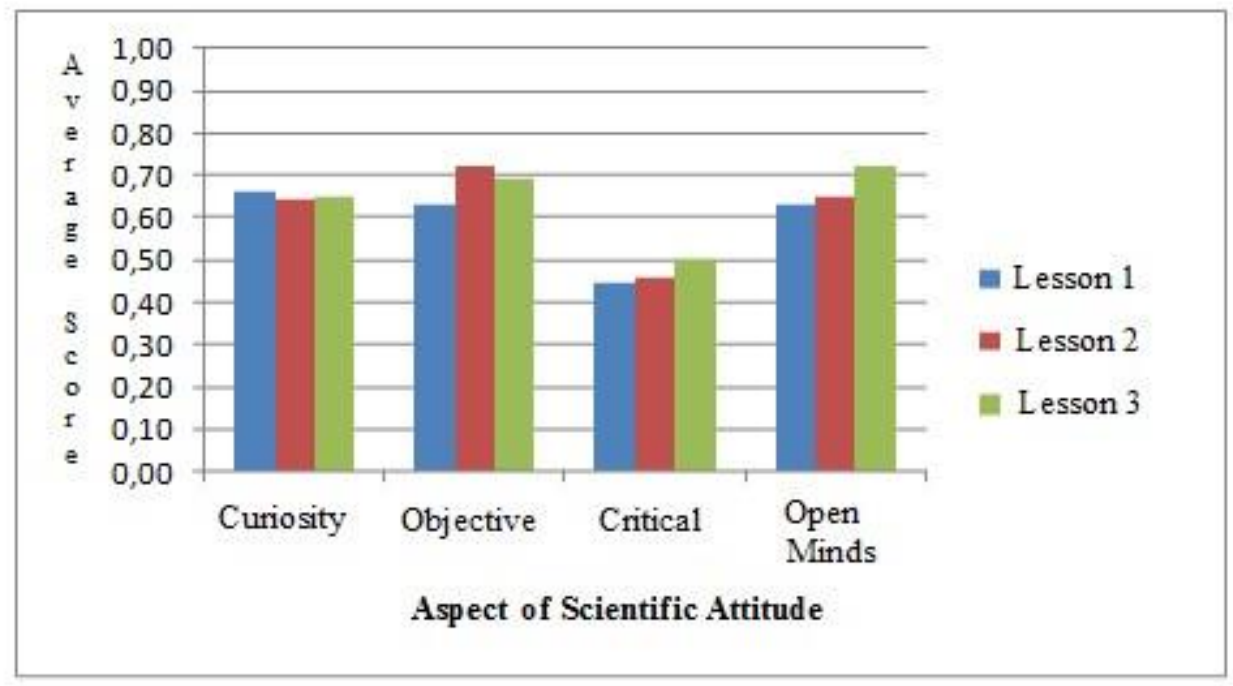

Figure 2. Diagram Scientific Attitude Measurement Results Through Observation Sheet (Maximum Score 1)

The results of measurements of the curious aspects of the meeting of the second and third it is smaller than the first meeting, it may be because at the initial meeting learners have understood the learning patterns in the stage of learning cycle so that for the next meeting of the students have prepared themselves well and the resulting decline in question submitted to the teacher as a form indicator of curiosity. Detachment at the second meeting was higher than another meeting, this can be caused by experiments at the second meeting learners simpler and easier to compare the experimental results with the theory.

Aspects of open-minded tend to increase, this is because at the next meeting some of the students have been accustomed to criticism to friends who are presenting. The response to criticism is then observed and measured as indicators of open-minded. Figure 2 describes the measurement results of scientific attitude through the observation sheet more clearly.

Self-assessment performed on stage Evaluate each meeting. The measurement results of scientific attitude through self-assessment and recap the average results for the third meeting. The recap of $5.56 \%$ based learners achieve excellent category, $75.93 \%$ good category, and $18.52 \%$ enough category. Analyzes every aspect of a scientific attitude through self-assessment can be observed in Table 38. On average every aspect of scientific attitude has a maximum score of 4 . 
Table 2. Analysis of Results of Measurement Scientific Attitude Through SelfAssessment

\begin{tabular}{|c|c|c|c|c|c|c|c|}
\hline \multirow[t]{2}{*}{ No } & \multirow{2}{*}{$\begin{array}{l}\text { Aspects of } \\
\text { Scientific } \\
\text { Attitude }\end{array}$} & \multicolumn{3}{|c|}{$\begin{array}{l}\text { Average score } \\
\text { Meeting }\end{array}$} & \multirow[t]{2}{*}{ Average } & \multirow{2}{*}{$\begin{array}{c}\text { Avarage } \\
\text { Scale } 4 \\
\end{array}$} & \multirow[t]{2}{*}{ Category } \\
\hline & & 1 & 2 & 3 & & & \\
\hline 1 & Curiosity & 2,91 & 3,00 & 3,00 & 2,97 & $\mathrm{~B}$ & 2,91 \\
\hline 2 & Objective & 2,96 & 2,94 & 2,90 & 2,94 & $\mathrm{~B}$ & 2,96 \\
\hline 3 & Critical & 2,69 & 2,72 & 2,67 & 2,69 & B & 2,69 \\
\hline 4 & Open minds & 3,37 & 3,06 & 3,28 & 3,23 & $\mathrm{~B}$ & 3,37 \\
\hline
\end{tabular}

Analysis of the results showed that all aspects of the scientific attitude was measured through self-assessment in both categories. Aspects minded had the highest mean score may be because most learners felt he could respect the opinions of others and can accept criticism.

As well as on limited testing, peer assessment done by assessing his students in one group at Evaluate stage. Data peer assessment results in detail, recap the score of each meeting and the average peer assessment results for the three meetings. Based on these results it can be seen that $3.70 \%$ of students got very good category, $79.63 \%$ and $16.67 \%$ good category category enough. Analysis of measurement results every aspect of scientific attitudes through peer assessment with a mean maximum score of 4 can be seen in Table 3 .

Table 3. Analysis of Scientific Attitude Measurement Through Rate Between Friends

\begin{tabular}{|c|c|c|c|c|c|c|c|}
\hline \multirow[t]{2}{*}{ No } & \multirow{2}{*}{$\begin{array}{c}\text { Aspects of } \\
\text { Scientific } \\
\text { Attitude }\end{array}$} & \multicolumn{3}{|c|}{$\begin{array}{l}\text { Average score } \\
\text { Meeting }\end{array}$} & \multirow[t]{2}{*}{ Average } & \multirow{2}{*}{$\begin{array}{c}\text { Avarage } \\
\text { Scale } 4\end{array}$} & \multirow[t]{2}{*}{ Category } \\
\hline & & 1 & 2 & 3 & & & \\
\hline 1 & Curiosity & 2,62 & 2,67 & 2,64 & 2,64 & B & 2,62 \\
\hline 2 & Objective & 2,90 & 2,97 & 2,88 & 2,91 & B & 2,90 \\
\hline 3 & Critical & 2,68 & 2,71 & 2,68 & 2,69 & B & 2,68 \\
\hline 4 & Open minds & 2,73 & 3,02 & 2,97 & 2,91 & B & 2,73 \\
\hline
\end{tabular}

The analysis showed that the four aspects of scientific attitudes derive either category. If you be more detailed, objective attitude and thinking aspects tebuka had an average score higher than the other two aspects. Peer assessment is done at the end of learning, and behavior that becomes the attitude indicator friends who rated emerged from beginning to end during the learning takes place. Such conditions can affect the measurements made on his students, because as expressed Vali (2012: 28) measurement errors can be caused by the inaccuracy of the parties conducting the measurements. The high average objective and 
open-minded attitude to the peer assessment may be influenced by easier items on the assessment of these aspects to be observed when compared to grain appear on other aspects of behavior.

\section{Conclusion}

This research resulted in: (1) integrated science instruction assessment practical through feasibility testing in the classroom science lessons with the following characteristics: (a) the observation sheet form checklist used by teachers to observe the science process skills of learners is only at the stage of disengagement, explore and explain, as well as observing the scientific attitude on stage elicit, engage, explore, explain, elaborate and extend (b) science process skills is not observed from the behavior of learners assessed by working the worksheet that includes aspects of prediction, communication in writing, inference, interpretation of data and use numbers (c) the self-assessment attitude assessment of scientific and scientific attitudes among learners friends used only at the stage of Evaluate (2) the instrument has been developed fit for use because it meets the content validity by experts and reliability was good value. (3) Results of measurement using observation sheet science process skills get a very good category in the aspect of observation, experimentation and communication through presentations and both categories on aspects of communication through discussion, while using the ratings based worksheet to get a good category in all aspects. The results of measuring scientific attitude of learners using observation sheets, selfassessment and peer assessment obtained either category on aspects of curiosity, objective, critical and open-minded.

\section{Acknowledgement}

Acknowledgements aimed at the Directorate of Research and the Community Service, The Ministry of Research Technology and Higher Education, with the support of research grant funding for the Graduate scheme in 2015.

\section{Reference}

Aiken, L. (1985). Three Coefficients for Analyzing The Reliability and Validity of Rating. Educational and Psychological Measurement , 45, 131-142.

Arends, R.I. (2013). Belajar untuk Mengajar. Learning to Teach. Jakarta: Salemba Empat.

Aydin, A. (2013). representation of Science Process Skills in the Chemistry Curricula for Grades 10,11 and 12/Turkey. International Journal of Education and Practice , 1, 5163. 
Borich, G. (1994). Observation Skill for Effective Teaching. New York: Macmillan Publishing Company.

Chiapetta, E., \& Koballa, T. (2010). Science Instruction in the Middle and Secondary Schools:Developing Fundamntal Knowledge and Skill, seventh edition. Boston: Allyn and Bacon.

Kemendikbud. (2014). Materi Pelatihan Guru Implementasi Kurikulum 2013 Tahun Ajaran 2014/2015. Jakarta: Kementrian Pendidikan dan Kebudayaan.

Martin, D. (2006). Elementary Science Methods. A Constructivist Approach. USA: Thomson Wadsworth.

McMillan, J. (2014). Classroom Assessment. Principles and Practice for Effective StandardsBased Instruction. USA: Pearson.

Mendikbud. (2014). Lampiran Peraturan Menteri Pendidikan dan Kebudayaan Republik Indonesia Nomor 104 Tahun 2014 Tentang Penilaian Hasil Belajar oleh Pendidik pada Pendidikan Dasar Pendidikan Menengah. Jakarta: Mendikbud.

MNitko, A., \& Brookhart, S. (2011). Educational Assessment of Students. USA: Pearson.

Oloruntegbe, K. (2010). Approaches To The Assessment Of Science Process Skills : A Reconceptualist View and Option. Journal of College Teaching \& Learning , 7, 11-18.

Popham, W. (2005). Classroom Assessment, What Teachers Need to Know. USA: Allyn and Bacon.

Qarareh, A. (2012). The Effect of Using the Learning Cycle Method in Teaching Science on the Educational Achievement of the Sixth Graders. International Journal Education Science, 4, 123-132.

Rauf, R., Rasul, M., Mansor, A., \& al., e. (2013). Inculcation of Science Process Skills In A Science Classroom Asian Social Science. Asian Social Science , 9, 47-57.

Rezba, R., Sprague, C., Fiel, R., Funk, H., Okey, J., \& Jaus, H. (1995). Learning and Assessing Science Process Skills. USA: Kendal/ Hunt Publishing Company.

Rosana, D. (2014). Evaluasi Pembelajaran Sains (Asesmen Pendekatan Saintifik Pembelajaran). Yogyakarta.

Sukmadinata, N. (2013). Metode Penelitian Pendidikan. Bandung: Remaja Rosdakarya.

Widoyoko, E. (2009). Evaluasi Program Pembelajaran. Yogyakarta: Pustaka Pelajar. 
